\title{
Compositional Variations and Floatabiblity of Kimberlite Ores of Russia
}

Spetsius, Z.V., and Bezborodov, S.M.

“Almazy Rossii-Sakha “ Co Ltd., Mirny, Yakutia, 678170, Russia

\section{Introduction}

Our long-term experience of treatment of kimberlite ores from various pipes has shown that floatability qualities and other properties of diamonds from various ores is not identical (Spetsius, 1996). Basically, it is possible to recognize two groups of kimberlite ores by floatability. Kimberlites from pipes: Sytykanskaya, Yubileinaya, Internatsionalnaya, Zarnitsa, and top horizons of Udachnaya pipe are poorly floated. Diamonds float good when processing ores from deep levels of the Udachnaya pipe (approximately from $50 \mathrm{~m}$ and lower), deep levels of Mir and Aikhal pipes, ores of Arkhangelsk province - Lomonosovskaja and Karpinskaja pipes. On the basis of the comparison of kimberlite ores with various floatability an attempt is undertaken to reveal distinctions in material composition of poorly and well floating kimberlites.

\section{Discussion}

The basic feature of the composition of all poorly floating kimberlite ores is their significant alteration by secondary processes, which are evidenced by intensive serpentinization and carbonatization of kimberlites, and also by development of a number of secondary hydrothermal minerals. At present, vertical zonality of kimberlite pipes on an example of the Udachnaya and others is rather reliably determined (Marshintsev, 1986; Zinchuk at al., 1993; Spetsius, 1996), showing with depth a decrease in intensity of metasomatic and hydrothermal alteration processes, that is reflected both on the petro- and geochemistry and on the mineral composition of rocks.

The upper parts of all the above-mentioned pipes with poorly floatable ores are subject to hypergene alterations and are characterized by the presence of a crust of weathering about 50 $\mathrm{m}$ down from a surface, in which hydrothermal and even clayey minerals like montmorillonite evolved. Free quartz and chalcedony, hydroxides of iron - hematite, goethite, and also a number of sulfides and sulfates (Zinchuk at al., 1993) have been revealed in the upper, touched by weathering, parts of the pipes Mir, Udachnaya and Aykhal. On the whole, it is possible to speak about wide prevalence of minerals from the group of oxides and hydroxides in the upper level of almost all of kimberlite pipes and about the oxidized composition of ores, changing with depth with the more reduced paragenetic association of minerals.

According to the results of recalculation of major chemical analyses, petrographic surveys data and semiquantitative X-ray diffraction analyses, the main components of kimberlite ores in Mir, Udachnaya and other pipes are serpentine and calcite, which together make $80-90 \%$ of volume, with their content being rather stable with depth, while the serpentine content slightly decreases downwards through the Udachnaya pipe (Zinchuk at al., 1993). Calcite prevails in the bulk of kimberlite of Sytykanskaya pipe up to depth of $200 \mathrm{~m}$, only in the lower parts of this pipe the serpentine content grows. For all ores of the upper levels of kimberlite pipes the presence of phlogopite and chlorite is the distinctive characteristics, their amount in the sum makes about $10 \%$, the content of these minerals is interdependent. The chlorite content with depth is systematically decreased, and this regularity is a distinctive characteristic of all kimberlite pipes. 
Essential component of all kimberlite ores is a constantly significant amount of fragments of host sedimentary rocks, represented by limestones, marls and other differences, the amounts of which are also reduced downwards within the pipes. For example, at the upper levels of Udachnaya pipe (295-250 m level) they amounted to more than $20 \%$ by volume, at the level of $190 \mathrm{~m}-15 \%$ by volume, and at the level of $-65 \mathrm{~m}$ there were only about $15 \%$. At the same time, according to the results of industrial experiments and laboratory tests, limestones and, especially, the dolomites from the host sedimentary rocks of Udachnaya pipe are good natural suppressers.

The chemistry of kimberlite rocks with different floatability is also different. In particular, rather regular change of chemistry with depth is defined for Udachnaya pipe on the comparative analysis data from five key levels. On the background of an increase in general magnesianity there is a decrease in content of calcium and iron oxides, and also carbon dioxide (Zinchuk at al., 1993). Downwards within a pipe, a change of silica-aluminous compositions on magnesian and ferrous ones is observed. By their major element chemistry the more altered kimberlites, in particular, of western body and upper levels of Udachnaya pipe are characterized by an increasing in contents of $\mathrm{CaO}, \mathrm{Al}_{2} \mathrm{O}_{3}, \mathrm{~K}_{2} \mathrm{O}$ and $\mathrm{CO}_{2}$, and the ores of deeper levels and east body of the pipe differ by an increased content of $\mathrm{MgO}, \mathrm{FeO}$ and $\mathrm{TiO}_{2}$. Also with depth, distinctions in concentration of microimpurities of $\mathrm{Ni}, \mathrm{Co}, \mathrm{Cr}$ and $\mathrm{V}$ are registered.

At the moment, it is possible to speak with certainty only about one pipe - Udachnaya - where a change in the floatability of ores is fixed: from poorly floatable in the upper part up to depth of 100-120 m and well floatable at the deeper levels. It is necessary to emphasize, that at the level of about $100 \mathrm{~m}$, practically there were not registered any noticeable changes in the kimberlite types or in their mineral composition. However, at this level there was an essential decrease in content of secondary minerals, in particular, barite, celestine, strontianite, thochilinite, quartz, and vein calcite. Approximately at the same level it is fixed, that in the most kimberlite composition of the given pipe a decrease in phlogopite and chlorite content was observed, and also perovskite has become to prevail instead of widely spread ore pyrite and magnetite in the basic and binding mass of kimberlites. Naturally, the fresh olivine content has increased with depth through the whole pipe and, especially, in its western body.

For the comparative analysis, it is interesting to compare material composition of kimberlite rocks of Yakutian province with those of Arkhangelsk province, in which, according to sampling of kimberlites of some pipes at the experimental Plant, the process of flotation has good indications. As all pipes of the latter province are also very intensively altered and their upper parts are represented by strongly weathered differences, it is possible to declare, that the basic difference between them and strongly altered kimberlite ores in Yakutia with poor floatability can be reduced to the following major factors: 1) evolution of saponite instead of serpentine, as the basic secondary mineral; 2) highly magnesian compositions of rocks; 3 ) various compositions of xenogenous fragments of host sedimentary rocks, represented first of all by quartz-feldspar rocks: sandstones, aleurolites and argillites.

The final estimation of one major or probably several interdependent factors, determining floatation characteristics of kimberlite ores, requires additional special laboratory experiments. As the tests conducted in 1977-80 on the emulsifiability and floatation characteristics of the basic secondary minerals of kimberlites of the Udachnaya pipe, have not revealed reliable regularities. Laboratory experiments, begun at the end of the last years on floatability of diamonds with the use of ore extracts from a thoroughly studied drill cores from deep levels of the Aykhal pipe, have not shown yet any regular dependence on their elemental composition. 


\section{Conclusions}

Thus, generalizing distinctions in material composition of the well and poorly floatable kimberlite ores, it is possible to note that poorly floatable kimberlites are characterized with the strong alterations, saturation with fragments of sedimentary rocks, first of all carbonaceous, intensive carbonatization and serpentinization, presence of a large number of secondary minerals. Presence of pyrite in the bulk of rocks and oxidated composition of ores are also characteristic.

Analysis of these peculiarities and relationship with dresseability of ores by flotation allowed to conclude about connection the floatabiblity of kimberlites with their composition and divided two groups of kimberlites.

\section{References}

Marshintsev, V.K., 1986, The vertical heterogeneity of kimberlite bodies of Yakutia: Novosibirsk, 240 p. (in Russian)

Spetsius, Z.V., 1996, The properties of diamonds and kimberlite ores from primary deposits of Yakutia: Implication to Exploration. ICAM'96 Abstracts, Warsaw, Poland, p. 116.

Zinchuk, N.N, Spetsius, Z.V., Zuenko, V.V., and Zuev, V.M., 1993, Kimberlite Pipe Udachnaya: Novosibirsk, 146 p. (in Russian) 